\title{
Sphingopyxis soli sp. nov., isolated from landfill soil
}

Correspondence

Jin-Woo Bae

baejw@khu.ac.kr

\author{
Jung-Hye Choi, ${ }^{1}$ Min-Soo Kim, ${ }^{1,2}$ Mi-Ja Jung, ${ }^{1}$ Seong Woon Roh, ${ }^{1,2}$
} Kee-Sun Shin ${ }^{2}$ and Jin-Woo Bae ${ }^{1}$

\author{
${ }^{1}$ Department of Life and Nanopharmaceutical Sciences and Department of Biology, \\ Kyung Hee University, Seoul 130-701, Republic of Korea \\ ${ }^{2}$ University of Science and Technology, BRC, KRIBB, Daejeon 305-333, Republic of Korea
}

The genus Sphingopyxis was proposed by Takeuchi et al. (2001) and classified in the family Sphingomonadaceae. At the time of writing, the genus comprises 11 recognized species: Sphingopyxis alaskensis (Vancanneyt et al., 2001), S. baekryungensis (Yoon et al., 2005), S. chilensis (Godoy et al., 2003), S. flavimaris (Yoon \& Oh, 2005), S. ginsengisoli (Lee et al., 2008), S. litoris (Kim et al., 2008), S. macrogoltabida (Takeuchi et al., 2001), S. marina (Kim et al., 2008), S. taejonensis (Pal et al., 2006), S. terrae (Takeuchi et al., 2001) and S. witflariensis (Kämpfer et al., 2002). Members of the genus Sphingopyxis are yellow- or whitish-brown-pigmented, Gram-negative, aerobic, non-spore-forming, motile or non-motile and with DNA G+C contents of 58$69.2 \mathrm{~mol} \%$ (Lee et al., 2008). They are chemotaxonomically characterized by the presence of $2-\mathrm{OH}$ fatty acids but the absence of 3-OH fatty acids, and the presence of ubiquinone Q-10 and spermidine. Sphingoglycolipids have been detected in all strains of the genera Sphingomonas sensu strictu, Sphingobium, Novosphingobium and Sphingosinicella (Pal et al., 2006; Takeuchi et al., 2001). In this paper, we describe the morphological, biochemical and phylogenetic characteristics of a Sphingopyxis-like strain, BL03 ${ }^{\mathrm{T}}$, employ-

The GenBank/EMBL/DDBJ accession number for the 16S rRNA gene sequence of strain BL03 ${ }^{\top}$ is FJ599671.

A two-dimensional thin-layer chromatogram of polar lipids of strain $\mathrm{BLO3}^{\top}$ is available with the online version of this paper. ing Sphingopyxis taejonensis JSS54 $4^{\mathrm{T}}$, Sphingopyxis alaskensis $\mathrm{RB} 2256^{\mathrm{T}}$ and Sphingopyxis chilensis $\mathrm{S} 37^{\mathrm{T}}$ as reference strains in parallel tests.

Strain $\mathrm{BL} 03^{\mathrm{T}}$ was isolated from landfill soil in Pohang, Korea, by plating the sample on Luria-Bertani broth (LB; BBL) agar plates at $30{ }^{\circ} \mathrm{C}$ for 3 days. On LB agar plates, strain $\mathrm{BL} 03^{\mathrm{T}}$ formed colonies that were yellow, circular, convex and entire. For phylogenetic analysis, genomic DNA was extracted as described by Sambrook et al. (1989). The 16S rRNA gene of strain BL03 ${ }^{\mathrm{T}}$ was amplified by using the colony PCR method with two universal bacterial primers (Baker et al., 2003). 16S rRNA gene sequence analysis was carried out by using the BigDye Terminator Cycle Sequencing Ready Reaction kit (Applied Biosystems) and an automated DNA analyser system (PRISM 3730XL DNA analyser; Applied Biosystems) according to the manufacturer's instructions. The $16 \mathrm{~S}$ rRNA gene sequence of strain $\mathrm{BL} 03^{\mathrm{T}}$ was compared with known sequences in the GenBank database of the NCBI, and was aligned by using the multiple sequence alignment program CLUSTAL X (1.83) (Thompson et al., 1997). The phylogenetic relationships between strain $\mathrm{BL} 03^{\mathrm{T}}$ and representative species of the genus Sphingopyxis were determined by using the program MEGA 4 (Tamura et al., 2007). A phylogenetic consensus tree was reconstructed by means of bootstrap analysis based on the neighbour-joining (Saitou \& Nei, 1987), maximum-parsimony (Felsenstein, 1981) and maximum- 
likelihood (Kluge \& Farris, 1969) methods. The numbers of bootstrap replicates were set to 1000, 1000 and 300, respectively. Phylogenetic analysis indicated that strain $\mathrm{BLO3}^{\mathrm{T}}$ should be classified in the genus Sphingopyxis and was closely related to Sphingopyxis taejonensis JSS54 ${ }^{\mathrm{T}}$ (Fig. 1). Strain BL03 ${ }^{\mathrm{T}}$ showed highest levels of $16 \mathrm{~S}$ rRNA gene sequence similarity to Sphingopyxis taejonensis JSS54 $4^{\mathrm{T}}$ $(97.8 \%)$, Sphingopyxis alaskensis RB2256 ${ }^{\mathrm{T}}(97.4 \%)$ and Sphingopyxis chilensis $\mathrm{S}^{7} 7^{\mathrm{T}}$ (96.9\%).

Genomic DNA was extracted from strain $\mathrm{BL} 03^{\mathrm{T}}$, the three reference strains, and Escherichia coli $\mathrm{K}-12$, as a calibration reference, according to Sambrook et al. (1989). The DNA $\mathrm{G}+\mathrm{C}$ content was determined by the fluorometric method (Gonzalez \& Saiz-Jimenez, 2002) by using SYBR Green I and a real-time PCR thermocycler (Bio-Rad). The DNA $\mathrm{G}+\mathrm{C}$ content of strain $\mathrm{BL} 03^{\mathrm{T}}$ was $65.9 \mathrm{~mol} \%$, within the range reported for members of the genus Sphingopyxis. DNA-DNA hybridizations were performed by using the method of Ezaki et al. (1989) as amended by Hirayama et al. (1996) with dry-adsorption immobilization. The results showed that strain $\mathrm{BL} 03^{\mathrm{T}}$ had low levels of DNADNA relatedness to Sphingopyxis taejonensis JSS54 $4^{\mathrm{T}}$ (40.3\%), Sphingopyxis alaskensis RB2256 ${ }^{\mathrm{T}}(34.7 \%)$ and Sphingopyxis chilensis $\mathrm{S} 37^{\mathrm{T}}$ (10.3\%).

The cell morphology of strain $\mathrm{BL} 3^{\mathrm{T}}$ was determined by light microscopy (ECLIPSE $80 i$; Nikon). The Gram reaction was performed according to the non-staining method described by Buck (1982). The presence of flagella was determined by using the flagella staining method (Heimbrook et al., 1989). To determine the physiologically optimal conditions for growth, strain $\mathrm{BL} 03^{\mathrm{T}}$ was incubated on LB agar for 2 days at various temperatures $(4,10,15$, 20, 25, 30, 37 and $\left.42{ }^{\circ} \mathrm{C}\right), \mathrm{NaCl}$ concentrations $(0,1,2,3,4$,
$5,6,8,10,12$ and $14 \%, \mathrm{w} / \mathrm{v})$ and $\mathrm{pH}(5.0-10.0$ at increments of $0.5 \mathrm{pH}$ units). Biochemical tests for enzyme activities and the utilization of substrates as sole carbon source were carried out by using API 20NE and API ZYM kits (bioMérieux) and Biolog GN2 microplate assays, according to the manufacturers' protocols. Hydrolysis of DNA and casein was determined by using DNase test agar (BBL) and skimmed milk (BBL), respectively, as described by Atlas (1993). Hydrolysis of cellulose was tested according to the method of Gerhardt et al. (1994). Catalase and oxidase activities were tested in $3 \%(\mathrm{v} / \mathrm{v})$ hydrogen peroxide solution (Hanker \& Rabin, 1975) and $1 \%(\mathrm{w} / \mathrm{v}) p$-tetramethyl phenylenediamine (bioMérieux), respectively.

Cells of strain $\mathrm{BL} 03^{\mathrm{T}}$ were Gram-negative, non-flagellated rods. The strain grew at $15-42{ }^{\circ} \mathrm{C}$, at $\mathrm{pH} 5.0-9.5$ and in the presence of $0-3 \%(\mathrm{w} / \mathrm{v}) \mathrm{NaCl}$. Optimal growth occurred at $30{ }^{\circ} \mathrm{C}$, at $\mathrm{pH} 6.0$ and in the presence of $0 \% \mathrm{NaCl}$. Strain $\mathrm{BL}^{\mathrm{T}}{ }^{\mathrm{T}}$ was catalase-negative and oxidase-positive. DNA was hydrolysed but casein and cellulose were not. The biochemical characteristics of strain $\mathrm{BL} 03^{\mathrm{T}}$ are given in the species description below and in Table 1 .

For fatty acid analysis, cells of strain $\mathrm{BL} 03^{\mathrm{T}}$ and the three Sphingopyxis reference strains were harvested from LB agar plates after incubation at $30{ }^{\circ} \mathrm{C}$ for 2 days. Cellular fatty acids were extracted according to the protocol of the Microbial Identification System (MIDI). The cellular fatty acid composition was analysed quantitatively by GC (Hewlett Packard 6890) and by using the MIDI System (Sasser, 1990). The predominant cellular fatty acids of strain $\mathrm{BL}_{03}{ }^{\mathrm{T}}$ were $\mathrm{C}_{17: 1} \omega 6 c$ (44.2\% of the total), $\mathrm{C}_{15: 0} 2$ $\mathrm{OH}(14.7 \%)$ and $\mathrm{C}_{18: 1} \omega 7 c(10.6 \%)$. The cellular fatty acid profile of strain $\mathrm{BL} 03^{\mathrm{T}}$ was similar to those of Sphingopyxis

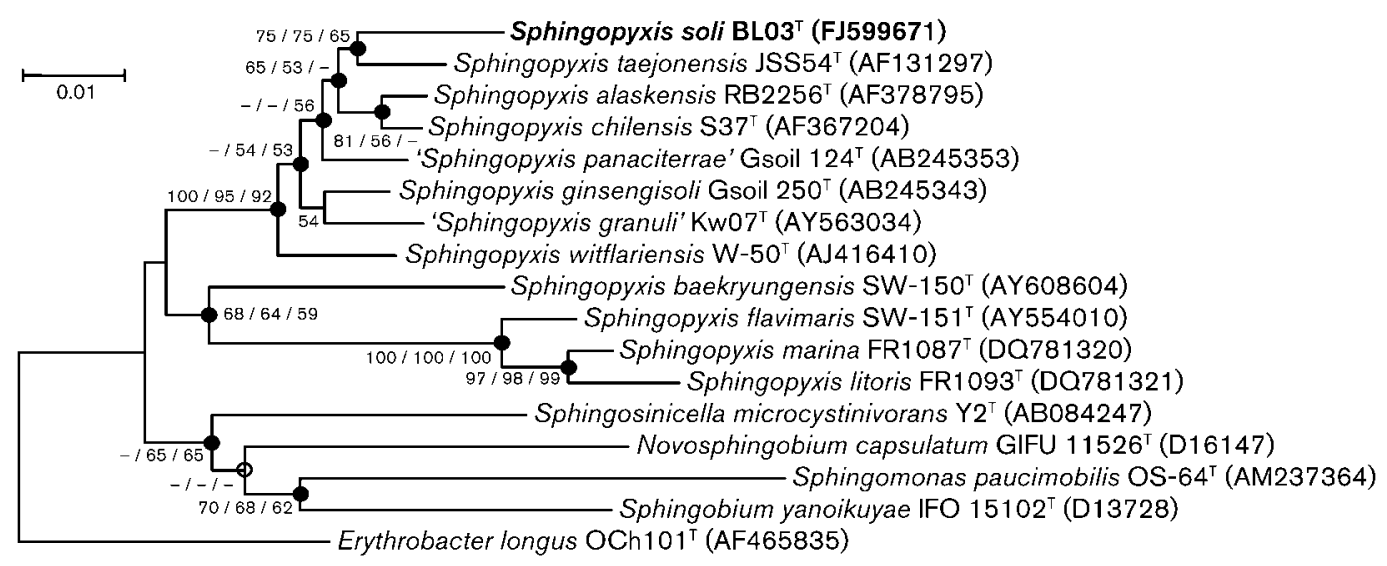

Fig. 1. Phylogenetic consensus tree based on $16 \mathrm{~S}$ rRNA gene sequences showing the relationship between strain $B L 03^{\top}$ and the type strains of closely related sphingomonads. The tree was reconstructed by using the neighbour-joining, maximumparsimony and maximum-likelihood methods; numbers at nodes represent bootstrap values (based on 1000, 1000 and 300 resamplings, respectively). Filled circles and empty circles indicate generic branches that were found by using the neighbourjoining, maximum-parsimony and maximum-likelihood algorithms, and by using the neighbour-joining and maximum-likelihood algorithms, respectively. GenBank accession numbers are given in parentheses. Pseudomonas antarctica KJPB5 $4^{\top}$ was used as the outgroup (not shown). Bar, 0.01 substitutions per nucleotide position. 
Table 1. Physiological and biochemical characteristics of strain $\mathrm{BLO}^{\mathrm{T}}$ and the type strains of related species of the genus Sphingopyxis

Strains: $1, \mathrm{BL}^{\mathrm{T}}{ }^{\mathrm{T}} ; 2$, Sphingopyxis taejonensis $\mathrm{JSS} 54^{\mathrm{T}} ; 3$, S. alaskensis $\mathrm{RB} 2256^{\mathrm{T}} ; 4$, S. chilensis $\mathrm{S} 37^{\mathrm{T}}$. Data are from the present study. All strains were positive for hydrolysis of casein, D-glucose utilization, and alkaline phosphatase, esterase (C4), esterase lipase (C8), leucine arylamidase, acid phosphatase and naphthol-AS-BI-phosphohydrolase activities. All strains were negative for hydrolysis of gelatin and casein, utilization of arabinose, mannitol, acetylglucosamine, potassium gluconate, capric acid, adipic acid, trisodium citrate and phenylacetic acid, reduction of nitrates to nitrites, indole production, glucose fermentation, and catalase, arginine hydrolase, galactosidase, lipase (C14), $\alpha$-galactosidase, $\beta$-galactosidase, $\beta$-glucosidase, $\alpha$ mannosidase and $\alpha$-fucosidase activities. - , Negative; + , positive; $\mathrm{W}$, weakly positive.

\begin{tabular}{|lcccc|}
\hline Characteristic & $\mathbf{1}$ & $\mathbf{2}$ & $\mathbf{3}$ & $\mathbf{4}$ \\
\hline Hydrolysis of: & & & & \\
$\quad$ Urea & + & - & - & - \\
Aesculin & + & - & - & + \\
DNA & + & + & + & - \\
Cellulose & - & + & - & - \\
Utilization of: & & & & \\
$\quad$ Mannose & - & - & - & + \\
Maltose & + & - & + & + \\
$\quad$ Malic acid & - & + & + & + \\
Activity of: & & & & \\
$\quad$ Valine arylamidase & + & + & - & $\mathrm{W}$ \\
Cystine arylamidase & - & $\mathrm{W}$ & $\mathrm{W}$ & - \\
Trypsin & + & $\mathrm{w}$ & $\mathrm{W}$ & - \\
$\alpha$-Chymotrypsin & - & + & - & - \\
$\beta$-Glucuronidase & - & - & + & - \\
$\alpha$-Glucosidase & + & - & + & $\mathrm{w}$ \\
$\quad N$-acetyl- $\beta$-glucosaminidase & - & - & - & + \\
\hline
\end{tabular}

alaskensis $\mathrm{RB} 2256^{\mathrm{T}}$ and Sphingopyxis chilensis $\mathrm{S} 37^{\mathrm{T}}$. The detailed fatty acid profile of strain $\mathrm{BL}^{\mathrm{T}}{ }^{\mathrm{T}}$ is given in Table 2 .

For analysis of polyamines, cells were cultivated in nutrient agar medium at $30{ }^{\circ} \mathrm{C}$. Polyamines were extracted according to Busse \& Auling (1988) and were analysed by HPLC as described by Stolz et al. (2007). Strain BL03 ${ }^{\mathrm{T}}$ exhibited a polyamine pattern with spermidine as the predominant compound, and 1,3-diaminopropane, putrescine and spermine as minor components $[<1.0 \mu \mathrm{mol}$ (g dry weight $\left.)^{-1}\right]$. The polyamine patterns of Sphingopyxis taejonensis JSS54 $4^{\mathrm{T}}$, Sphingopyxis chilensis $\mathrm{S} 37^{\mathrm{T}}$ and Sphingopyxis alaskensis RB2256 ${ }^{\mathrm{T}}$, which were examined concurrently, were similar (Table 2). These results are in good agreement with those reported by Takeuchi et al. (2001) and Busse et al. (1999) and support the classification of strain $\mathrm{BL} 03^{\mathrm{T}}$ within the genus Sphingopyxis.

Polar lipids were extracted according to Xin et al. (2000), and were identified by two-dimensional TLC, as described by Tindall (1990). Major polar lipids of strain $\mathrm{BL} 03^{\mathrm{T}}$ were diphosphatidylglycerol, phosphatidylcholine, phosphatidyl-
Table 2. Polyamine and fatty acid components of strain $B L 03^{\top}$ and related reference strains

Strains: $1, \mathrm{BL} 03^{\mathrm{T}} ; 2$, Sphingopyxis taejonensis $\mathrm{JSS} 54^{\mathrm{T}} ; 3$, S. alaskensis $\mathrm{RB} 2256^{\mathrm{T}} ; 4$, S. chilensis $\mathrm{S} 37^{\mathrm{T}}$. Data are from the present study. $\mathrm{t}$, $<0.1 \%$; $\mathrm{Tr}$, trace $(<1.0 \%)$; $\mathrm{ND}$, not detected; fatty acids that comprised $<1.0 \%$ of the total in all strains are omitted.

\begin{tabular}{|c|c|c|c|c|}
\hline Cellular component & 1 & 2 & 3 & 4 \\
\hline \multicolumn{5}{|c|}{ Polyamines $\left[\mu \mathrm{mol}(\mathrm{g} \text { dry weight })^{-1}\right]$} \\
\hline 1,4-Diaminopropane & $\mathrm{t}$ & $\mathrm{t}$ & $\mathrm{t}$ & $\mathrm{t}$ \\
\hline Putrescine & 0.6 & 0.4 & 0.5 & 0.7 \\
\hline Spermidine & 18.2 & 13.9 & 9.2 & 13.3 \\
\hline Spermine & 0.4 & 0.3 & 0.1 & 0.2 \\
\hline \multicolumn{5}{|l|}{ Fatty acids (\%) } \\
\hline $\mathrm{C}_{15: 0}$ & 3.9 & 1.5 & 4.4 & 6.8 \\
\hline $\mathrm{C}_{16: 0}$ & 4.7 & 12.8 & 3.0 & 3.1 \\
\hline $\mathrm{C}_{17: 0}$ & 4.5 & $\operatorname{Tr}$ & 5.4 & 3.0 \\
\hline $\mathrm{C}_{14: 0} 2-\mathrm{OH}$ & 1.3 & 7.4 & 1.3 & 2.0 \\
\hline $\mathrm{C}_{15: 0} 2-\mathrm{OH}$ & 14.7 & 3.6 & 22.7 & 25.2 \\
\hline $\mathrm{C}_{16: 0} 2-\mathrm{OH}$ & 1.1 & 3.5 & 1.3 & $\operatorname{Tr}$ \\
\hline $\mathrm{C}_{16: 1} \omega 5 c$ & 1.2 & 1.3 & $\operatorname{Tr}$ & $\operatorname{Tr}$ \\
\hline $\mathrm{C}_{17: 1} \omega 8 c$ & 6.9 & 1.0 & 8.3 & 6.8 \\
\hline $\mathrm{C}_{17: 1} \omega 6 c$ & 44.2 & 6.3 & 27.4 & 29.0 \\
\hline $\mathrm{C}_{18: 1} \omega 7 c$ & 10.6 & 30.3 & 14.9 & 10.5 \\
\hline $\mathrm{C}_{18: 1} \omega 5 c$ & $\operatorname{Tr}$ & 1.6 & $\operatorname{Tr}$ & 1.7 \\
\hline 11-Methyl $C_{18: 1} \omega 7 c$ & 2.0 & 9.1 & 6.4 & 4.2 \\
\hline Summed feature $3^{*}$ & 2.9 & 19.0 & 1.6 & 4.0 \\
\hline Summed feature $7^{\star}$ & ND & ND & 2.1 & $\operatorname{Tr}$ \\
\hline
\end{tabular}

${ }^{*}$ Summed feature 3 comprises $\mathrm{C}_{16: 1} \omega 7 c$ and/or iso- $\mathrm{C}_{15: 0} 2-\mathrm{OH}$; summed feature 7 comprises $\mathrm{C}_{19: 1}$ cyclo $\omega 10 c$ and/or $\mathrm{C}_{19: 1} \omega 6 c$.

ethanolamine, phosphatidylglycerol, phosphatidylmonomethylethanolamine, sphingoglycolipid, an unknown phospholipid and an unknown glycolipid (Fig. 2 and Supplementary Fig. S1). The polar lipid profile of strain $\mathrm{BL}^{\mathrm{T}}{ }^{\mathrm{T}}$ corresponded to those reported for sphingomonads (Busse et al., 1999), and in particular for the genus Sphingopyxis (Kämpfer et al., 2002; Yoon et al., 2005; Yoon \& Oh, 2005).

On the basis of its phenotypic, genetic and phylogenetic characteristics, strain $\mathrm{BL} 03^{\mathrm{T}}$ is considered to represent a novel species of the genus Sphingopyxis, for which we propose the name Sphingopyxis soli sp. nov.

\section{Description of Sphingopyxis soli sp. nov.}

Sphingopyxis soli (so'li. L. gen. n. soli of soil, the source of the type strain).

Colonies are circular, convex, entire, yellow and 2.0$5.0 \mathrm{~mm}$ in diameter after cultivation for 5 days at $30{ }^{\circ} \mathrm{C}$. Cells are Gram-negative, aerobic and oxidase-positive. Grows at $15-42{ }^{\circ} \mathrm{C}$ (optimum, $30^{\circ} \mathrm{C}$ ), in the presence of $0-3 \%(\mathrm{w} / \mathrm{v}) \mathrm{NaCl}$ (optimum, $0 \%)$ and at $\mathrm{pH}$ 5-9.5 (optimum, pH 6.0). DNA is hydrolysed, but casein and cellulose are not. Positive reactions are obtained for aesculin, 


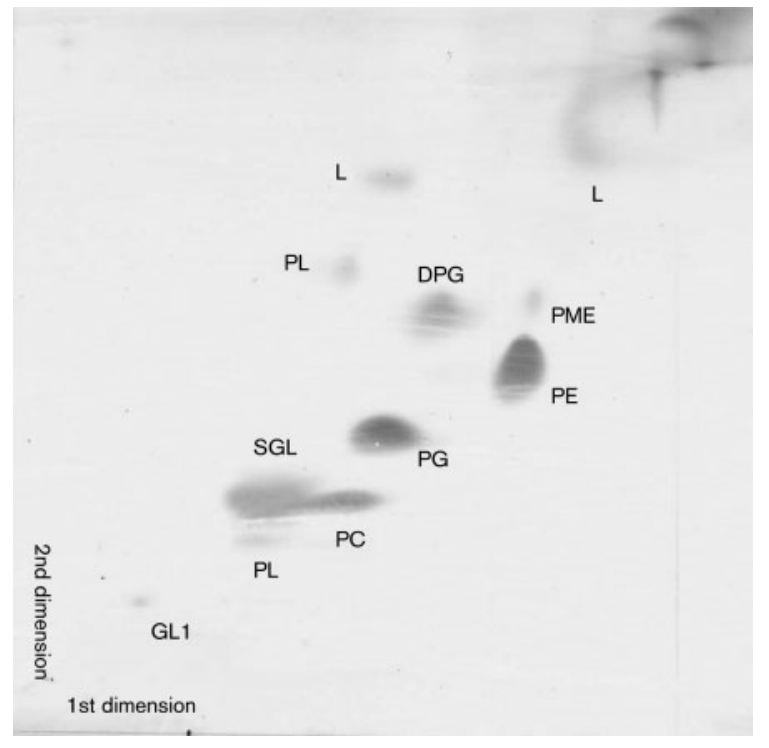

Fig. 2. Two-dimensional thin-layer chromatogram of polar lipids of strain $\mathrm{BLO3}^{\top}$. PC, phosphatidylcholine; PME, phosphatidylmonomethylethanolamine; DPG, diphosphatidylglycerol; PG, phosphatidylglycerol; PL, unknown phospholipid; PE, phosphatidylethanolamine; SGL, sphingoglycolipid; GL1, unknown glycolipid; L, unknown lipids.

glucose and maltose (API 20NE). Positive for alkaline phosphatase, esterase (C4), esterase lipase (C8), leucine arylamidase, valine arylamidase, trypsin, acid phosphatase, naphthol-AS-BI-phosphohydrolase and $\alpha$-glucosidase, but negative for lipase (C14), cystine arylamidase, $\alpha$-chymotrypsin, $\alpha$-galactosidase, $\beta$-galactosidase, $\beta$-glucuronidase, $\beta$ glucosidase, $\quad N$-acetyl- $\beta$-glucosaminidase, $\alpha$-mannosidase and $\alpha$-fucosidase (API ZYM). Utilizes dextrin, $N$-acetyl-Dglucosamine, adonitol, pyruvic acid methyl ester, $\beta$-hydroxybutyric acid, itaconic acid, DL-lactic acid, propionic acid, quinic acid, succinic acid, L-alanine, L-alanyl glycine, Laspartic acid, glycyl L-aspartic acid, glycyl L-glutamic acid, Lhistidine, L-leucine, L-ornithine, L-pyroglutamic acid, Lserine, $\gamma$-aminobutyric acid and D-glucose 6-phosphate (Biolog GN2). Other organic substrates are not utilized. Major fatty acids are $\mathrm{C}_{17: 1} \omega 6 c, \mathrm{C}_{15: 0} 2-\mathrm{OH}$ and $\mathrm{C}_{18: 1} \omega 7 c$. The DNA G $+\mathrm{C}$ content of the type strain is $65.9 \mathrm{~mol} \%$. Major polar lipids are phosphatidylethanolamine, diphosphatidylglycerol, phosphatidylcholine, phosphatidylglycerol, phosphatidylmonomethylethanolamine and sphingoglycolipid. Spermidine is the major polyamine component.

The type strain, BL03 ${ }^{\mathrm{T}}\left(=\mathrm{KCTC} 22405^{\mathrm{T}}=\mathrm{JCM} 15910^{\mathrm{T}}\right)$, was isolated from soil taken from a landfill in Pohang, Republic of Korea.

\section{Acknowledgements}

We are grateful to Hans-Jürgen Busse for analysis of the polyamine pattern and to Jean P. Euzéby (Ecole Nationale Vétérinaire, France) for etymological advice. This work was supported by the CAER (Center for Aquatic Ecosystem Restoration) of Eco-STAR project, the 21C Frontier Microbial Genomics and Application Center Program, the Eco-technopia 21 project and the Environmental Biotechnology National Core Research Center (KOSEF: R15-2003-012-02002-0).

\section{References}

Atlas, R. M. (1993). In Handbook of Microbiological Media. Edited by L. C. Parks. Boca Raton, FL: CRC Press.

Baker, G. C., Smith, J. J. \& Cowan, D. A. (2003). Review and reanalysis of domain-specific $16 \mathrm{~S}$ primers. J Microbiol Methods 55, 541555.

Buck, J. D. (1982). Nonstaining ( $\mathrm{KOH})$ method for determination of gram reactions of marine bacteria. Appl Environ Microbiol 44, 992993.

Busse, H.-J. \& Auling, G. (1988). Polyamine pattern as a chemotaxonomic marker within the Proteobacteria. Syst Appl Microbiol 11, 1-8.

Busse, H.-J., Kämpfer, P. \& Denner, E. B. M. (1999). Chemotaxonomic characterisation of Sphingomonas. J Ind Microbiol Biotechnol 23, 242-251.

Ezaki, T., Hashimoto, Y. \& Yabuuchi, E. (1989). Fluorometric deoxyribonucleic acid-deoxyribonucleic acid hybridization in microdilution wells as an alternative to membrane filter hybridization in which radioisotopes are used to determine genetic relatedness among bacterial strains. Int J Syst Bacteriol 39, 224-229.

Felsenstein, J. (1981). Evolutionary trees from DNA sequences: a maximum likelihood approach. J Mol Evol 17, 368-376.

Gerhardt, P., Murray, R. G. E., Wood, W. A. \& Krieg, N. R. (editors) (1994). Methods for General and Molecular Bacteriology. Washington, DC: American Society for Microbiology.

Godoy, F., Vancanneyt, M., Martinez, M., Steinbuchel, A., Swings, J. \& Rehm, B. H. A. (2003). Sphingopyxis chilensis sp. nov., a chlorophenol-degrading bacterium that accumulates polyhydroxyalkanoate and transfer of Sphingomonas alaskensis to Sphingopyxis alaskensis comb. nov. Int J Syst Evol Microbiol 53, 473-477.

Gonzalez, J. M. \& Saiz-Jimenez, C. (2002). A fluorimetric method for the estimation of $\mathrm{G}+\mathrm{C}$ mol\% content in microorganisms by thermal denaturation temperature. Environ Microbiol 4, 770-773.

Hanker, J. S. \& Rabin, A. N. (1975). Color reaction streak test for catalase-positive microorganisms. J Clin Microbiol 2, 463-464.

Heimbrook, M. E., Wang, W. L. \& Campbell, G. (1989). Staining bacterial flagella easily. J Clin Microbiol 27, 2612-2615.

Hirayama, H., Tamaoka, J. \& Horikoshi, K. (1996). Improved immobilization of DNA to microwell plates for DNA-DNA hybridization. Nucleic Acids Res 24, 4098-4099.

Kämpfer, P., Witzenberger, R., Denner, E., Busse, H.-J. \& Neef, A. (2002). Sphingopyxis witflariensis sp. nov., isolated from activated sludge. Int J Syst Evol Microbiol 52, 2029-2034.

Kim, B.-S., Lim, Y. W. \& Chun, J. (2008). Sphingopyxis marina sp. nov. and Sphingopyxis litoris sp. nov., isolated from seawater. Int J Syst Evol Microbiol 58, 2415-2419.

Kluge, A. G. \& Farris, J. S. (1969). Quantitative phyletics and the evolution of anurans. Syst Zool 18, 1-32.

Lee, M., Ten, L. N., Lee, H.-W., Oh, H. W., Im, W.-T. \& Lee, S.-T. (2008). Sphingopyxis ginsengisoli sp. nov., isolated from soil of a ginseng field in South Korea. Int J Syst Evol Microbiol 58, 2342-2347.

Pal, R., Bhasin, V. K. \& Lal, R. (2006). Proposal to reclassify [Sphingomonas] xenophaga Stolz et al. 2000 and [Sphingomonas] 
taejonensis Lee et al. 2001 as Sphingobium xenophagum comb. nov. and Sphingopyxis taejonensis comb. nov., respectively. Int J Syst Evol Microbiol 56, 667-670.

Saitou, N. \& Nei, M. (1987). The neighbor-joining method: a new method for reconstructing phylogenetic trees. Mol Biol Evol 4, 406425.

Sambrook, J., Fritsch, E. F. \& Maniatis, T. (1989). Molecular Cloning: a Laboratory Manual, 2nd edn. Cold Spring Harbor, NY: Cold Spring Harbor Laboratory.

Sasser, M. (1990). Identification of bacteria by gas chromatography of cellular fatty acids, MIDI Technical Note 101. Newark, DE: MIDI Inc.

Stolz, A., Busse, H.-J. \& Kämpfer, P. (2007). Pseudomonas knackmussii sp. nov. Int J Syst Evol Microbiol 57, 572-576.

Takeuchi, M., Hamana, K. \& Hiraishi, A. (2001). Proposal of the genus Sphingomonas sensu stricto and three new genera, Sphingobium, Novosphingobium and Sphingopyxis, on the basis of phylogenetic and chemotaxonomic analyses. Int J Syst Evol Microbiol 51, 14051417.

Tamura, K., Dudley, J., Nei, M. \& Kumar, S. (2007). MEGA4: molecular evolutionary genetics analysis (MEGA) software version 4.0. Mol Biol Evol 24, 1596-1599.
Thompson, J. D., Gibson, T. J., Plewniak, F., Jeanmougin, F. \& Higgins, D. G. (1997). The CLUSTAL_X windows interface: flexible strategies for multiple sequence alignment aided by quality analysis tools. Nucleic Acids Res 25, 4876-4882.

Tindall, B. J. (1990). Lipid composition of Halobacterium lacusprofundi. FEMS Microbiol Lett 66, 199-202.

Vancanneyt, M., Schut, F., Snauwaert, C., Goris, J., Swings, J. \& Gottschal, J. (2001). Sphingomonas alaskensis sp. nov., a dominant bacterium from a marine oligotrophic environment. Int J Syst Evol Microbiol 51, 73-79.

Xin, H., Itoh, T., Zhou, P., Suzuki, K., Kamekura, M. \& Nakase, T. (2000). Natrinema versiforme sp. nov., an extremely halophilic archaeon from Aibi salt lake, Xinjiang, China. Int J Syst Evol Microbiol 50, 1297-1303.

Yoon, J.-H. \& Oh, T.-K. (2005). Sphingopyxis flavimaris sp. nov., isolated from sea water of the Yellow Sea in Korea. Int J Syst Evol Microbiol 55, 369-373.

Yoon, J.-H., Lee, C.-H., Yeo, S.-H. \& Oh, T.-K. (2005). Sphingopyxis baekryungensis sp. nov., an orange-pigmented bacterium isolated from sea water of the Yellow Sea in Korea. Int J Syst Evol Microbiol 55, 1223-1227. 